\title{
What my 5-year-old son taught me about medicine
}

$\mathrm{R}$ ecently, I took my five-year-old son, Max, with me to round on my patients at the nursing home I visit weekly. As I entered the facility I saw Anni (not her real name), my 101-year-old German-speaking patient who has severe dementia. She is always irritable, agitated and uncooperative with me. To be honest, I am a bit scared of her: being screamed at in German is uncomfortable for a Jew.

I felt hesitant and unsure at first. The left side of her forehead is covered with a large patch of basal cells that she often scratches. How would my 5 -year-old son react to her? Would he be scared? I took a deep breath and held my son's hand and we went up to Anni to say hello.

As soon as Anni saw Max, she underwent an astonishing transformation. I was amazed to see her large, welcoming, warm smile. My son took her hand and she began repeating guten Morgen with care and love. My son patiently held her hand, stared into her face without fear or inhibition. He looked curiously and with the authentic interest only a child has. He had never seen a face covered in basal cells before but he was calm, watching and listening to her. He was without judgment. She then changed her mantra to the word Tante, Tante with a loving smile, motioning to herself. I have never heard anything like this from her. She had formed a new connection.

This precious communion between the two only lasted a few minutes. Max said goodbye to Anni and we left. Only later as I recounted the day's events to my wife, did I realize the significance of this experience. My visit with Anni the next week was equally remarkable. This woman with severe dementia, reached out to hold my hand with a smile for the first time ever. She held my hand with care and attention. In that single interaction, Max taught me many lessons about the doctor-patient relationship.

1. Human Contact - Max held Anni's hand with compassion and care. Human contact with my patients had

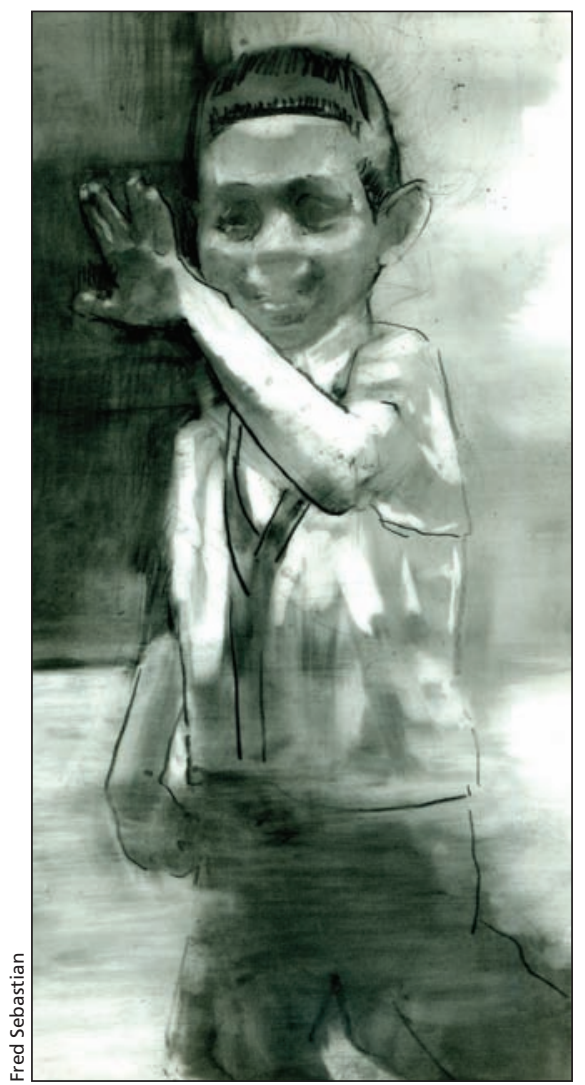

always been taboo for me, although after 10 years in clinical practice I now realize that sometimes it's okay. We live in a culture and profession where we fear and are cautioned about inappropriate touching but this simple contact with a patient transfers a wealth of communication beyond words. It says I care, I am here for you, you are important, I want to help, I am with you.

2. Mindfulness - Max's mind is so focused on the moment. He can become lost in fun playing with a stick or dancing around my house with underwear on his head. Max practises what Dr. Jon Kabat-Zinn calls mindfulness. He is fully engaged in the moment, not worrying or planning some future event. I worry about where I should be going, what I should be doing or what I just did. Max just is. During those minutes at the nursing home with Anni, Max was in the moment. He focused his attention on her, sharing his time and concentration.

3. Time - As physicians we are busy with endless professional duties during the day. Most of us know the stress of falling behind and keeping patients waiting. There are phone calls to make, patients to see and charting and email to do. There is never enough time. However within each clinical encounter we can create an experience that is unique for every patient. We can make eye contact, or use body language, posture and seating position to establish a truly special encounter. Max naturally accomplished this with Anni.

4. Smile - Max and Anni smiled at each other during their experience. In most initial encounters with patients, a smile eases tension and opens the channels of communication. Finding a smile can be challenging when you're dealing with a patient who had a miscarriage or a discussion about a new diagnosis of cancer. Somehow though, smiling is contagious and it lightens the load.

5. Happiness - In the few minutes Max and Anni were together, I could see that Anni was happy. She did not tell me, but it was obvious by her smile, demeanour and behaviour. This made me remember a lecture I attended by internationally recognized expert on the topic of happiness, Dr. John Helliwell. He reported that one of the key indicators of happiness is trust. Anni seemed to have trusted Max and perhaps by extension, the nursing home staff. Trust helps create a sense of community in the nursing home.

Max and I continue to go on house calls together and he continues to teach his daddy the art of medicine.

\section{Daniel Y. Dodek MD \\ Family physician \\ Vancouver, BC}

CMAJ 2013. DOI:10.1503/cmaj.121697 